\title{
Wine quality under integrated, organic and biodynamic management using image-forming methods and sensory analysis
}

\author{
Jürgen Fritz ${ }^{1,2^{*}}$, Johanna Döring ${ }^{3}$, Miriam Athmann ${ }^{1}$, Georg Meissner ${ }^{3}$, Randolf Kauer ${ }^{3}$ and Hans R. Schultz
}

\begin{abstract}
Background and aims: The image-forming methods copper chloride crystallization, capillary dynamolysis and circular chromatography are presented as an instrument for assessing wine quality. Wine quality of samples from a long-term field trial comparing integrated, organic and biodynamic management were investigated by using imageforming methods and sensory analysis.

Methods and results: Concerning the image-forming methods copper chloride crystallization, capillary dynamolysis and circular chromatography, the images of encoded samples were (i) grouped into pairs with similar image features; (ii) characterized based on reference images (e. g. high-low resistance to degradation); (iii) ranked (according to the characterization), and (iv) assigned to the different production methods (classified). Wine samples from organic and biodynamic management needed less wine per sample for a similar expression of structural characteristics than wine samples from integrated cultivation. Organic and biodynamic samples also show structures that indicate less degeneration than integrated samples. Due to these properties, nine coded wine samples from 2010 could be (i) grouped, (ii) characterized, (iii) ranked and (iv) classified without errors, i.e., assigned to the cultivation methods of integrated, organic and biodynamic agriculture. In sensory analysis, the wine derived from biodynamic management had the highest aroma intensity. In the other parameters the differences were not significant.
\end{abstract}

Conclusion: Analysis with the image-forming methods copper chloride crystallization, capillary dynamolysis and circular chromatography complements sensory analysis for a more complete description of the characteristic properties of wines originating from different management systems.

Significance of the study: If further studies confirm these results, the image-forming methods copper chloride crystallization, capillary dynamolysis and circular chromatography may be developed as a complementary tool to sensory and chemical analysis in assessing wine quality.

Keywords: Sensory analysis, Image-forming methods, Copper chloride crystallization, Circular chromatography, Wine quality, Integrated, Organic, Biodynamic viticulture

\section{Background}

Demand and production of permanent crops originating from organic or biodynamic farming are growing around the world [1]. The share of organic and biodynamic

\footnotetext{
*Correspondence: j.fritz@uni-kassel.de

1 Department of Organic Farming and Cropping Systems, University

of Kassel, Nordbahnhofstr. 1a, 37213 Witzenhausen, Germany

Full list of author information is available at the end of the article
}

production for permanent crops is high in proportion to arable crops or grassland. Especially in Europe, organic and biodynamic viticulture spread rapidly in the last 20 years and have now reached a surface of almost 400,000 ha [1].

In order to compare integrated, organic and biodynamic viticultural systems, a long-term field trial was set up in Geisenheim, Germany, in 2006 (INBIODYN 
systems comparison trial, [2]). The three production systems showed marked differences on vine growth and yield [2-5], while chemical analyses carried out to describe the quality of the wines originating from the different management systems showed only slight differences in the period of conversion [5]. This is well in accordance with meta-analyses, revealing heterogeneous effects of organic and biodynamic management on winegrape and wine quality $[3,6]$. In the current study, we describe results from wine quality investigations with sensory analyses and the image-forming methods copper chloride crystallization, capillary dynamolysis and circular chromatography, carried out complementary to chemical analyses for samples from the INBIODYN trial in the fifth year after conversion.

Out of the three image-forming methods applied, the methodology of image production and evaluation has been most profoundly described for copper chloride crystallization. The basis of the copper chloride crystallization method is that when an aqueous copper(II) chloride solution $\left(\mathrm{CuCl}_{2}-2 \mathrm{H}_{2} \mathrm{O}\right)$ with additives is crystallized on a glass plate, additive-specific crystallization patterns are formed [7, 8]. The patterns are formed by a selforganization process influenced by the additive $[9,10]$. Developmental series of physiological processes such as maturation and degeneration become visible in the crystal images through a typical systematic structural change $[11,12]$.

The crystallization process and the laboratory method have been described and documented by Busscher et al. $[7,13]$ and Kahl et al. [14]. For the visual evaluation of the copper chloride crystallization patterns, defined morphological criteria according to the ISO-Norm 11035 [15] for sensory analysis were developed [16] A computer-aided texture and structure analysis was also developed for the crystal structures [17-20]. Studies are currently being carried out to describe the physical conditions for the crystallization process $[7,21]$. Computer image analysis of the crystal structures of copper chloride crystallization images could distinguish conventional and organic wheat samples [19, 22]. With visual evaluation of copper chloride crystallization, capillary dynamolysis and circular chromatography-encoded samples from organic and conventional production systems could repeatedly be classified according to the cultivation method [12, 23-28].

Various studies were conducted to reveal the influence of different viticultural management systems on wine sensory characteristics, but outcomes are ambiguous [3]. While several studies did not observe differences in sensory characteristics of conventional and organic wines either derived from field trials $[5,29,30]$ or commercial wineries [31, 32], some other studies detected differences in sensory attributes when quantitative descriptive analysis was applied, but results are not consistent. Wines from conventional viticulture were described as complex, vegetal, floral, and fruity [5, 31], whereas biodynamic wines were perceived as more balanced and fullbodied with a stronger minerality [5]. Organically grown Vitis vinifera L. cv. Cabernet Sauvignon wines from Australia were described as being more rich, vibrant and complex compared to conventional wines from the same randomized field trial [33]. While organically grown Vitis labrusca cv. Seyval wines from the US and Vitis vinifera L. cv. Sangiovese wines from Italy were preferred by panelists compared to their conventional counterparts [34, 35], organically grown Trebbiano wines from Italy were described as unbalanced and acidic compared to conventional Trebbiano wines from the same trial [34]. Investigation of the influence of biodynamic viticultural practices on wine quality and wine sensory characteristics has been a topic in current research, especially as compared to organic management. In several studies on Vitis vinifera L. cv. Grüner Veltliner, Cabernet Sauvignon, and Sangiovese, no differences in wine sensory characteristics were observed [29, 33, 36, 37]. In contrast, Meißner [5], Ross et al. [38] and Parpinello et al. [39] detected differences in the preference or in the sensory properties of biodynamic and organic Riesling, Merlot and Sangiovese wines, respectively.

A recent study from Italy shows that the winemaking process (conventional vs. biodynamic) highly influences wine quality. Conventional and biodynamic winemaking protocols for Sangiovese red wines were compared over two consecutive seasons resulting in a higher intensity of cherry and floral odors in the biodynamic wines. The latter were produced without addition of industrial yeast or bacteria [40].

The grape juices, constituting the wines of the present study, have been thoroughly researched in previous studies. Herein the image-forming methods proved to be sensitive indicators for the effects of different growth conditions [25, 41]. Therefore, the hypothesis for the present study was: (i) image-forming methods generate different and complementary information compared to sensory analysis and (ii) with the image-forming methods, wine from the cultivation methods integrated, organic and biodynamic can be differentiated, characterized and classified, as growth processes influenced by site conditions have a significant impact on the product quality of wine.

\section{Materials and methods}

\section{Experimental site and management}

Wine samples from the vintage 2010 were taken from a long-term field trial comparing different cultivation systems at Hochschule Geisenheim University, Geisenheim, 
Germany ([2]; see Tab. 1). The experimental site is a 0.8ha vineyard (Vitis vinifera L. cv. Riesling, clone Gm19830, grafted on Vitis berlandieri Planch. $\times$ Vitis riparia Michx. cv. SO4 and Vitis riparia Michx. $\times$ Vitis cinerea Engelm. cv. Börner rootstock, respectively) at Geisenheim $\left(49^{\circ} 59^{\prime} ; 7^{\circ} 56\right)$, Germany. The vines were planted in 1991 at a spacing of $1.2 \mathrm{~m}$ within rows and $2 \mathrm{~m}$ between rows. The pruning system is single guyot with about $6-8$ buds $\mathrm{m}^{-2}$. The vineyard was managed using good agricultural practice (GAP) until 2005. Since January 2006, the vineyard has been divided into replicate plots of integrated (GAP), organic and biodynamic viticulture (both according to EU regulations $834 / 07$ and 889/08). The experiment was setup as a complete block design, where the three factor levels of the main effect management system were replicated in four blocks. Each main plot for the factor management system consisted of two subplots, within which the two different rootstocks were equally distributed. Each plot included four rows with 32 vines each. Only the inner two rows of each plot were used for sample collection. The outer rows were considered as buffer rows. The main characteristics of the different treatments are specified in Table 1.

\section{Wine samples}

Grapes were hand-harvested on 10/13/2010 and transported to the Department of Oenology at Geisenheim University in boxes containing $25 \mathrm{~kg}$ each. Grapes from the different subplots (central rows without buffer rows) and field replicates were blended together in order to obtain three samples from the respective management systems. Wine samples were obtained by contemporaneous pressing of $300 \mathrm{~kg}$ grapes from the three management systems on EUROPRESS Px3 (EUROPRESS Umwelttechnik $\mathrm{GmbH}$, Lathen, Germany). Juices were sedimented overnight, racked and stored in two 25-L carboys per management system on 10/14/2010. Industrial yeast (Saccharomyces cerevisiae Oenoferm ${ }^{\circledR}$ Klosterneuburg,
Erbslöh, Geisenheim, Germany) was added to each sample $\left(30 \mathrm{~g}^{*} 100 \mathrm{l}^{-1}\right)$, and fermentation was controlled by regularly measuring relative density with a digital density meter (DMA 35 Basic, Anton Paar, Graz, Austria). Before samples were analyzed, they were degassed for $3 \mathrm{~min}$ in an ultrasonic bath. Samples from all three management systems showed similar fermentation patterns (Fig. 1).

After alcoholic fermentation was completed, wines were racked and the two replicates per management system were blended together in order to obtain one sample per management system. These samples were then analyzed using Fourier-transform infrared spectroscopy (FTIR) (FT2 Winescan, FOSS, Hillerød, Denmark), with the results presented in Table 2 .

The wine samples for performing image-forming methods were obtained from the integrated, organic and biodynamic management systems before bottling. By the staff of Geisenheim University nine samples were coded (three samples per farming system). Using the three image-forming methods copper chloride crystallization, capillary dynamolysis and circular chromatography, the samples were analyzed in the laboratory of the Department of Agroecology and Organic Farming at the University of Bonn. Nine samples (three repetitions per farming system) were assessed. All samples were delivered in wine bottles.

The wine was not filtered. In the laboratory, the wine was aged by opening the bottles and storing them at $20{ }^{\circ} \mathrm{C}$. For the first $48 \mathrm{~h}$, the bottle was open without a cap. Afterwards, from the 2nd to the 6th day of aging, the bottle had a vacuum closure (brand "vacuvin wine saver concerto"). From the 6th to the 114th day of aging the bottles were closed with a handle cork (natural cork). Each wine series was analyzed in a sequence with varying mixing ratio of wine and diluted metal salts as described below. By varying both aging times and mixing ratios of wine and diluted metal salts, the spectrum of images for the analysis of every sample was extended. 412 images

Table 1 Characterization of the different viticultural management practices (integrated, organic and biodynamic) used within the experimental trial (taken from [25])

\begin{tabular}{|c|c|c|c|}
\hline & Integrated & Organic & Biodynamic \\
\hline Perennial cover crops & Grass mixture & \multicolumn{2}{|c|}{ Diverse cover crop mixture (Wolff Mixture) } \\
\hline Annual cover crops & Rye + vetch & \multicolumn{2}{|c|}{ Diverse cover crop mixtures } \\
\hline Under vine management & Herbicides & \multicolumn{2}{|c|}{ Mechanical } \\
\hline Fertilization & $\begin{array}{l}\text { Compost + mineral + leg- } \\
\text { umes from annual cover } \\
\text { crops }\end{array}$ & \multicolumn{2}{|c|}{ Compost + legumes from perennial and annual cover crops } \\
\hline Plant protection & Organic fungicides & \multicolumn{2}{|c|}{ Copper (max $3 \mathrm{~kg} / \mathrm{ha}$ and year), sulfur, plant strengtheners } \\
\hline Biodynamic preparations & & & $\begin{array}{l}\text { Horn manure, horn silica, compost prepa- } \\
\text { rations }\end{array}$ \\
\hline
\end{tabular}




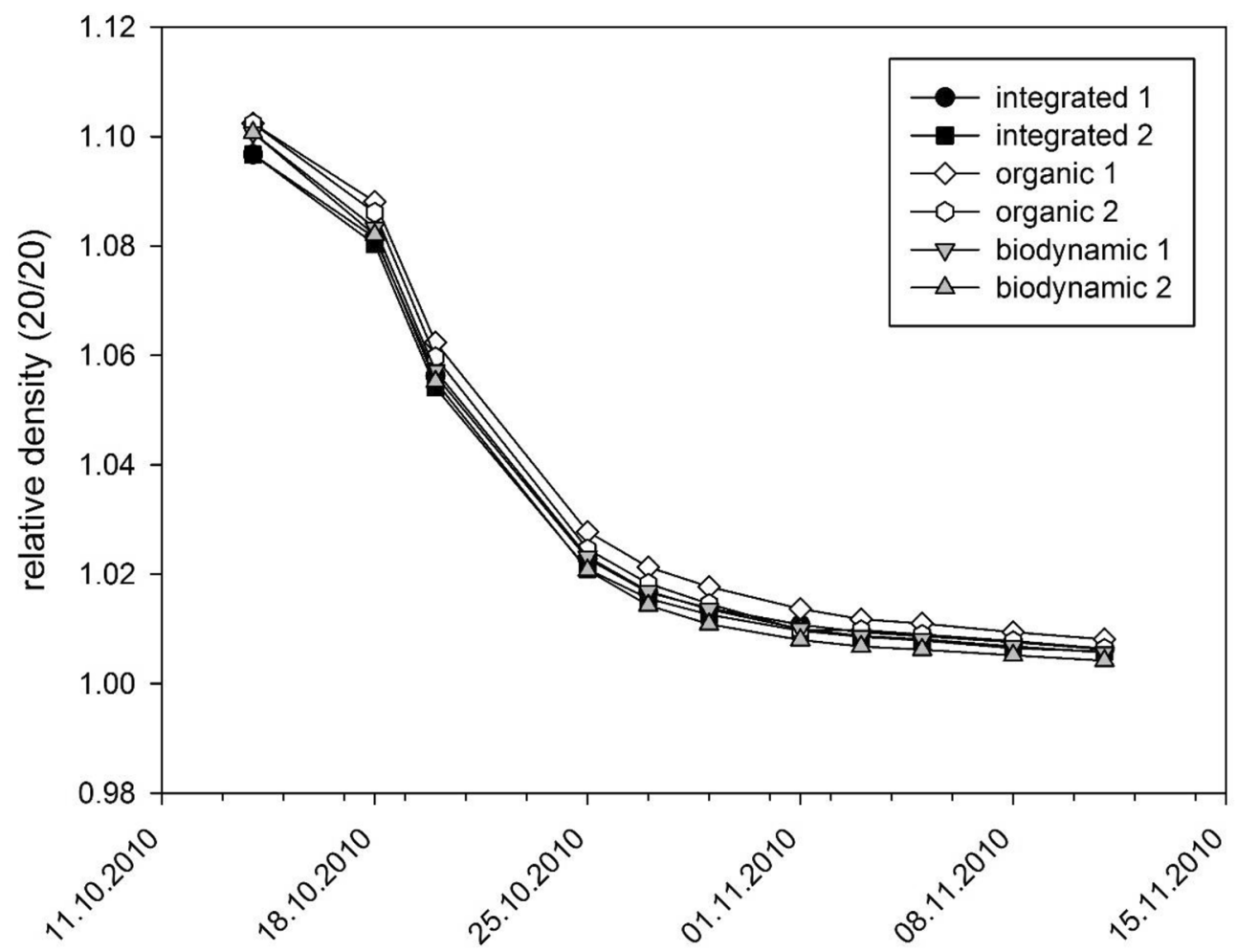

Fig. 1 Development of relative density (20/20) of juice samples deriving from different viticultural management systems during fermentation (vintage 2010). In order to be able to identify possible variations in wine production, fermentation was carried out in two different containers

Table 2 Chemical analysis of wines derived from the different management systems (vintage 2010) by FTIR

\begin{tabular}{llll}
\hline Parameter & Integrated & Organic & Biodynamic \\
\hline Relative density (20/20) & 1.0016 & 1.0022 & 1.0006 \\
Alcohol (\% vol.) & 11.5 & 12.1 & 12.3 \\
Residual sugars (g/l) & 14.0 & 14.7 & 11.2 \\
Glucose (g/l) & 2.1 & 2.2 & 1.3 \\
Fructose (g/l) & 7.5 & 7.3 & 5.1 \\
pH & 3.1 & 3.2 & 3.1 \\
Total acidity (g/l) & 12.7 & 13.5 & 13.4 \\
Tartaric acid (g/l) & 1.9 & 1.7 & 1.6 \\
Malic acid (g/l) & 8.3 & 8.8 & 8.6 \\
Lactic acid (g/l) & $\mathrm{n} . \mathrm{n}$ & $\mathrm{n} . \mathrm{n}$ & $\mathrm{n} . \mathrm{n}$ \\
Volatile acidity (g/l) & 0.8 & 0.7 & 0.6 \\
Glycerol (g/l) & 9.6 & 11.4 & 10.9 \\
\hline
\end{tabular}

were produced and evaluated. For an overview of mixing ratios, wine aging times and reagent composition in the images, see Table 3.

\section{Circular chromatography}

Filter paper discs (Whatman No. 1) with a total diameter of $15 \mathrm{~cm}$ were saturated to a diameter of $8 \mathrm{~cm}$ with
$0.5 \mathrm{ml}$ of a $0.5 \%$ silver nitrate solution. The filter papers were then dried for $2-3 \mathrm{~h} .0 .45 \mathrm{ml}, 0.50 \mathrm{ml}, 0.55 \mathrm{ml}$ and $0.60 \mathrm{ml}$ of wine were diluted with distilled water (water distilling devices Muldestor Wagner \& Munz) to a total volume of $0.77 \mathrm{ml}$. The samples were set at $20{ }^{\circ} \mathrm{C}$ with $0.48 \mathrm{ml} 0.8 \% \mathrm{NaOH}$ solution for $1 \mathrm{~h}$ (for mixing ratio see Tab. 3). The extract solution migrated through a central filter paper wick and the filter paper discs from the center to a diameter of $12 \mathrm{~cm}$. To maintain sufficient humidity, the paper was covered with a glass container. The images developed to full color within $48 \mathrm{~h}$ in diffuse daylight (not direct sunlight). From each of the nine samples, 16 circular chromatography images were made and evaluated.

\section{Capillary dynamolysis}

In the first phase, $0.45 \mathrm{ml}, 0.5 \mathrm{ml} 0.55 \mathrm{ml}$, and $0.6 \mathrm{ml}$ of wine were diluted with distilled water to a total volume of $0.6 \mathrm{ml}$. These liquids were applied to standard-sized chromatography paper (Schleicher \& Schuell 2043A) in Kaelin dishes and left to rise [42]. In the second phase, $0.7 \mathrm{ml}$ of a $0.25 \%$ silver nitrate solution rose to $1 \mathrm{~cm}$ across the line formerly formed by the juice. In the third phase, $2.0 \mathrm{ml}$ of a 0.25 percent iron sulfate solution rose to a total height of $12 \mathrm{~cm}$ (for mixing ratio, see Table 3). During the second and third phase, the chromatograms 
Table 3 Extract setting times, mixing ratio and reagent composition of the image-forming methods circular chromatography capillary dynamolysis and copper chloride crystallization

\begin{tabular}{|c|c|c|c|c|c|c|c|c|c|}
\hline \multirow[t]{2}{*}{ Method } & \multirow[t]{2}{*}{ Series } & \multirow{2}{*}{$\begin{array}{l}\text { Open bottle at } \\
20^{\circ} \mathrm{C}\end{array}$} & \multicolumn{7}{|l|}{ Per image } \\
\hline & & & Wine (ml) & $\mathrm{H}_{2} \mathrm{O}$ dest. (ml) & $\begin{array}{l}\mathrm{NaOH} \\
0.80 \% \\
(\mathrm{ml})\end{array}$ & $\begin{array}{l}\mathrm{AgNO}_{3} \\
0.25 \% \\
(\mathrm{ml})\end{array}$ & $\begin{array}{l}\mathrm{AgNO}_{3} \\
0.50 \% \\
(\mathrm{ml})\end{array}$ & $\begin{array}{l}\mathrm{FeSO}_{4} \\
0.25 \% \\
\text { (ml) }\end{array}$ & $\begin{array}{l}\mathrm{CuCl}_{2} 10 \% \\
\text { in } \mathrm{H}_{2} \mathrm{O} \\
(\mathrm{ml})\end{array}$ \\
\hline Circular chromatography & $\begin{array}{l}A \\
B \\
C \\
D\end{array}$ & $\begin{array}{l}0 d \\
1 d \\
2 d \\
4 d\end{array}$ & $\begin{array}{l}0.45 \\
0.50 \\
0.55 \\
0.60\end{array}$ & $\begin{array}{l}0.32 \\
0.27 \\
0.22 \\
0.17\end{array}$ & $\begin{array}{l}0.48 \\
0.48 \\
0.48 \\
0.48\end{array}$ & & $\begin{array}{l}0.50 \\
0.50 \\
0.50 \\
0.50\end{array}$ & & \\
\hline Capillary dynamolysis & A & $0 d$ & $\begin{array}{l}0.45 \\
0.50 \\
0.55 \\
0.60\end{array}$ & $\begin{array}{l}0.15 \\
0.10 \\
0.05 \\
0.00\end{array}$ & & $\begin{array}{l}0.70 \\
0.70 \\
0.70 \\
0.70\end{array}$ & & $\begin{array}{l}2.00 \\
2.00 \\
2.00 \\
2.00\end{array}$ & \\
\hline Copper chloride crystallization & $\begin{array}{l}A \\
B \\
C \\
D \\
E \\
F \\
G \\
H \\
I \\
J\end{array}$ & $\begin{array}{l}0 d \\
1 d \\
2 d \\
6 d \\
9 d \\
16 d \\
23 d \\
38 d \\
43 d \\
114 d\end{array}$ & $\begin{array}{c}1.0 \\
1.2 \\
1.4 \\
1.6\end{array}$ & $\begin{array}{c}2.0 \\
1.8 \\
1.6 \\
1.4\end{array}$ & & & & & $\begin{array}{l}2.0 \\
2.0 \\
2.0 \\
2.0\end{array}$ \\
\hline
\end{tabular}

Copper chloride crystallization mixing ratio:

- Serie $0 \mathrm{~d}$ and $1 \mathrm{~d}: 1.0 \mathrm{ml} ; 1.2 \mathrm{ml} ; 1.4 \mathrm{ml}$ wine

- Serie $2 \mathrm{~d}-114 \mathrm{~d}: 1.2 \mathrm{ml} ; 1.4 \mathrm{ml} ; 1.6 \mathrm{ml}$ wine

were covered with tall beakers to maintain sufficient humidity. The drying time between the individual phases was 2 hours at $20^{\circ} \mathrm{C}$ and $50 \%$ humidity. From each of the nine samples, 4 capillary dynamolysis images were made and evaluated.

\section{Copper chloride crystallization}

For the crystallization method, wine, distilled water and a 10 percent copper chloride solution were mixed (for mixing ratio, see Table 3 ). The solution was placed into Petri dishes $(100 \mathrm{~mm} \times 15 \mathrm{~mm}$ steriplan soda-lime-glass Duran Group) and crystallized in a crystallization chamber at $30{ }^{\circ} \mathrm{C}$ with $50 \%$ humidity for $12-15 \mathrm{~h}$ [41]. From each of the nine samples, 30 copper chloride crystallization images were made and evaluated.

\section{Analysis of wine samples with image-forming methods}

The visual image evaluation of the wine samples was based on reference images of grape juice and exemplary images of wine with (i) different levels of juice or wine quantity per plate and (ii) different levels of degeneration/ageing due to different periods of storage in open wine bottles. The calibration procedure also described in Fritz et al. [41] for grape juice was as follows: in the reference grape images and exemplary wine images, characteristic changes in the image structures that occurred (i) with increasing juice and wine quantity per plate and (ii) with increasing juice and wine deterioration were described using the criteria listed by Huber et al. [16].

These comparative series formed the basis for characterizing the images from the three production system as "strong-weak form expression" (wine-specific morphological features) and "fresh-deteriorated". Based on these characterizations, a qualitative assessment of the generated images was made, where (a1) wine with strong form expression and (b1) fresh opened wine bottle (wine exhibiting fewer decomposition features due to limited oxidative processes) was ranked higher than (a2) wine with weak form expression and (b2) a long time opened wine bottle. The encoded wine samples were grouped according to similar form expression and, based on experience from earlier investigations, assigned to cultivation methods (classification). The images were evaluated visually by 2 persons.

\section{Statistical analysis of image-forming methods}

For statistical analysis (see also [12]), the agreement between correct grouping/classification and the grouping/classification based on the results of the imageforming methods was tested. The test is based on a $3 \times 3$ contingency table, which compares a set of given categories to the ones determined in the investigation (see Tables 5 and 6). For the grouping test, Fisher's exact test was carried out. For the classification test, the agreement 
was determined with the simple Kappa coefficient. The methods are described by Agresti [43]. The statistical software ' $\mathrm{R}$ ', version 2.10.1 (R Development Core Team, $R$ Foundation for Statistical Computing, Vienna, Austria) was used for Fisher's exact test. Calculation of Kappa coefficients and exact p-values for testing agreement was carried out using PROC FREQ in SAS (SAS Institute Inc., Cary, NC, USA), version 9.3.

\section{Sensory analysis of the wines}

Sensory analysis of the wines from the vintage 2010 was performed on 04/09/2014 at Hochschule Geisenheim University within a Bachelor Thesis [44] with a trained panel consisting of students, staff of Hochschule Geisenheim University and winegrowers $(n=24)$. Descriptive analysis (attributes: acidity, freshness, fruit, aroma intensity, complexity, reduction, purity, typicity for variety Riesling, bitterness, body, ripeness) was performed. Before the tasting, fructose was added to the integrated and the biodynamic variant up to the same level of residual sugars as the organic variant. This was done to equalize sweetness in the wines and to prevent panelists from ranking according to levels of residual sugars. Samples were randomly encoded and the order of appearance of the samples was random for each panelist.

Statistics for the descriptive analyses were computed with the software R [45]. A mixed linear model with treatment as a fixed factor and panelist as random factor was applied. A likelihood ratio test was performed to test the significance of the factor treatment. If the treatment effect was significant $(p<0.1)$, a General Linear Hypothesis Test with Bonferroni-Holm adjustment was carried out to compare the factor levels.

\section{Results and discussion}

\section{Grouping based on circular chromatography images}

The grouping of the coded samples (i.e., the differentiation of the samples) was primarily done based on circular chromatography images. Characterization of the images with classification was carried out with the reference series of copper chloride crystallization images. In circular chromatography, three groups of images with similar characteristics were distinguished, each group consisting of three samples (Fig. 2):

- Group 1: clear brown outer ring; bright pink inner ring with some purple lines in the center of the pink inner ring.

- Group 2: paler brown outer ring; very bright pink inner ring with many purple lines in the center of the pink inner ring.
- Group 3: unclear brown outer ring; darker pink inner ring without purple lines; violet lines running towards the center of the white inner zone.

\section{Quality assessment and classification based on copper chloride crystallization images}

In the reference series for deterioration (Fig. 3), it was determined that

- with decreasing amount of wine per plate, the needle bundles turned from fine to coarse

- with increasing deterioration of the sample, the needle bundles turned from fine and even (fresh open bottle) to coarse, with wavy, brittle needle bundles, not uniformly structured from center to outside, partly with annular zones where needle coverage is low (bottle of wine that had been opened for 23 days).

In the different image series produced for comparing samples from the three production systems, the needle bundles in the images of the wine samples were increasingly coarser with less uniform needles in the following order:

- Series 1: 0 days $<1$ day $<2$ days open bottle (Fig. 4)

- Series 2: 9 days $<16$ days $<23$ days open bottle (Fig. 5)

- Series 3: 38 days $<43$ days $<114$ days open bottle (Fig. 6)

- Group $1<$ Group $2<$ Group 3 (in Figs. 4, 5, 6).

In earlier studies it was found that organic and especially biodynamic products show fewer signs of aging and degeneration and a stronger form expression than samples from conventional or integrated production (e.g., beetroot: [27], wheat: [24, 26]; rocket lettuce: [22]; grapes: $[25,41])$. Therefore, the group with the coarsest and least uniform needle bundles showing most signs of degeneration (group 3) was classified as from the integrated production system, the group with the finest needle bundles with the lowest degeneration (group 1) was classified as from the biodynamic production system and the group in between (group 2) was classified as from the organic production system.

Thus, in the present study, the cultivation methods showed a clear hierarchy of quality according to the criteria of strength of form expression and resistance to deterioration of biodynamic $>$ organic $>$ integrated (Table 4). Decoding showed that all samples were correctly grouped and classified (Tables 5 and 6). 


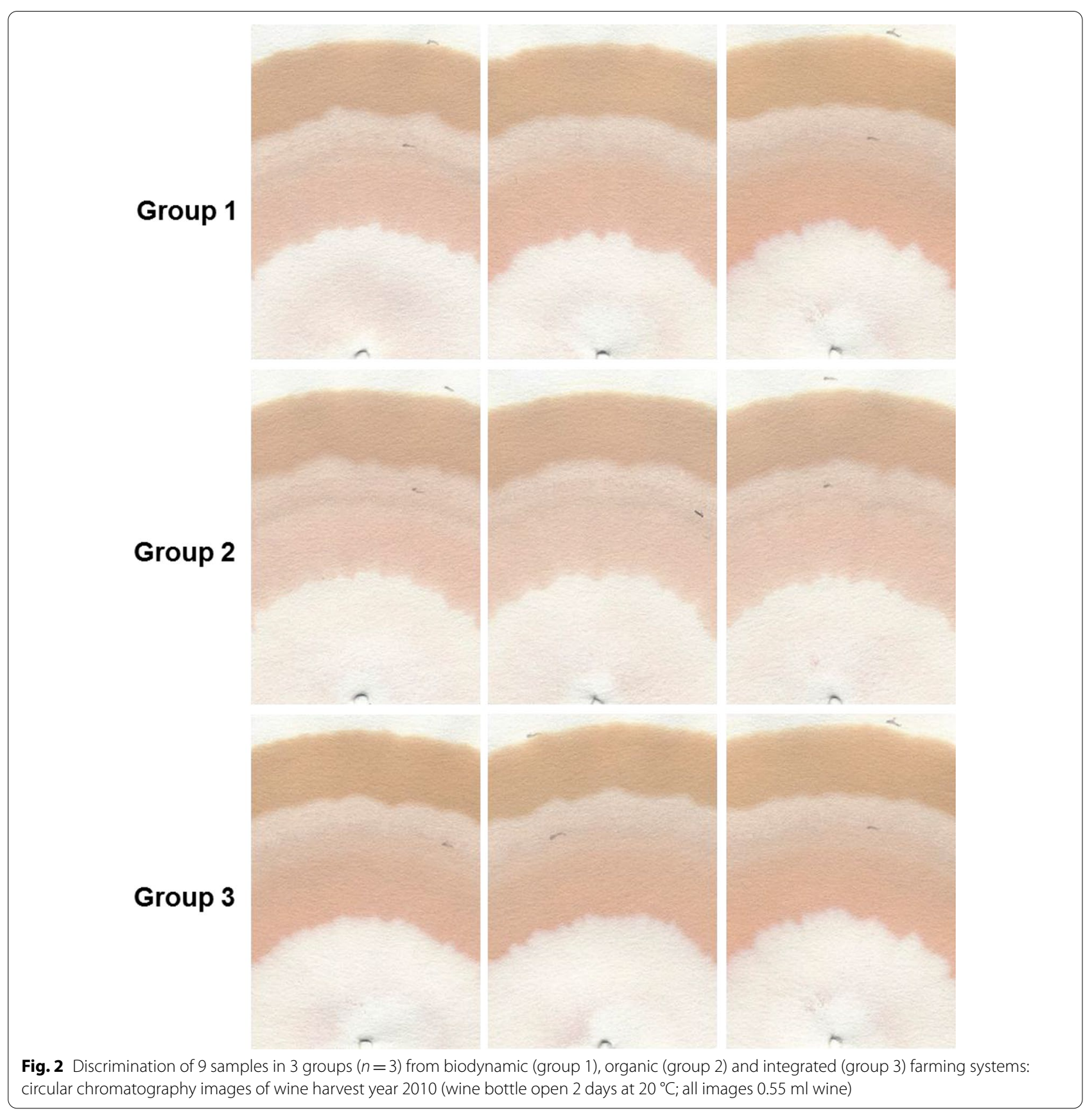

Each of the image-forming methods shows different aspects of the examined samples. Therefore, all three methods were used in parallel. In this study, circular chromatography was used to differentiate the samples into groups (sample repetitions). Copper chloride crystallization was especially well suited for quality assessment and sample classification (differences in strength of form expression and resistance to deterioration). In the present study, capillary dynamolysis did not further support the accuracy of the results. However, in other studies [12, 22], sample characterization relied strongly on this method. Therefore, the combined use of all three methods is recommended for investigations.

\section{Sensory analysis}

In the descriptive sensory analysis, the wines derived from biodynamic, organic and integrated viticulture were perceived to be slightly different. The wine from 


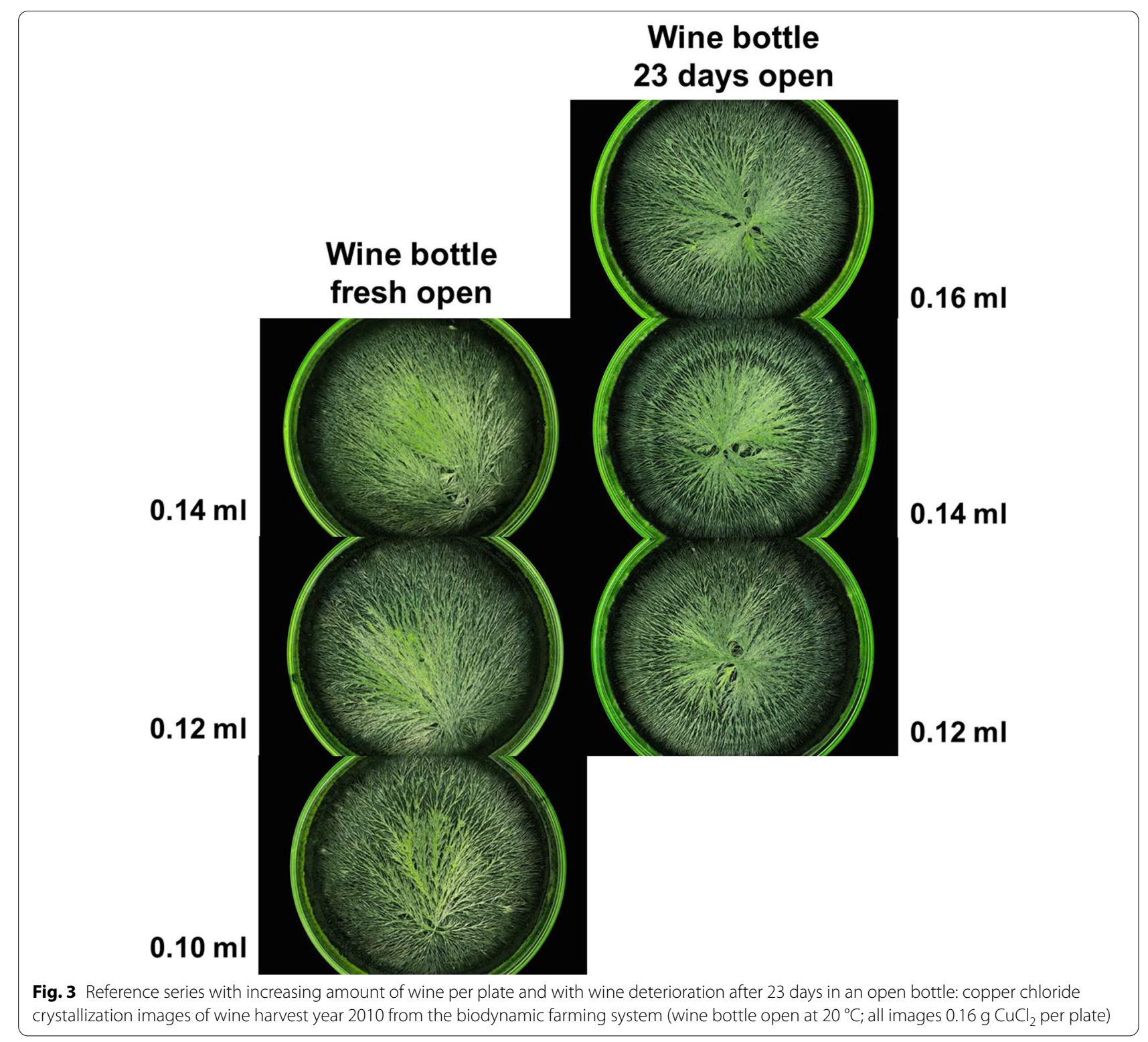

the biodynamic treatment showed a significantly higher aroma intensity compared to the wine from the integrated treatment $(p<0.1)$ (Fig. 7). The wine from the biodynamic treatment was also perceived as being the fruitiest and the freshest, but differences were not significant.

\section{Role of image-forming methods in wine quality assessment}

In the INBIODYN systems comparison trial, the three production systems systematically influenced growth and development of the vines, with low vegetative growth and low yield, loose grape structure and little acetic acid infestation in the organic and especially in the biodynamic treatment, and strong vegetative and generative growth with high shoot length of primary shoots, high pruning weight, single berry weight and grape yield, but also compact bunch structure and a higher share of sour rot on bunches in the integrated treatment $[2,4]$. These differences were consistent in the period of conversion from 2006-2009 described in Meißner et al. [2] and the following 3 years 2010-2012 described in Döring et al. [4]. Even though the different fertilization strategies in the two biological treatments 


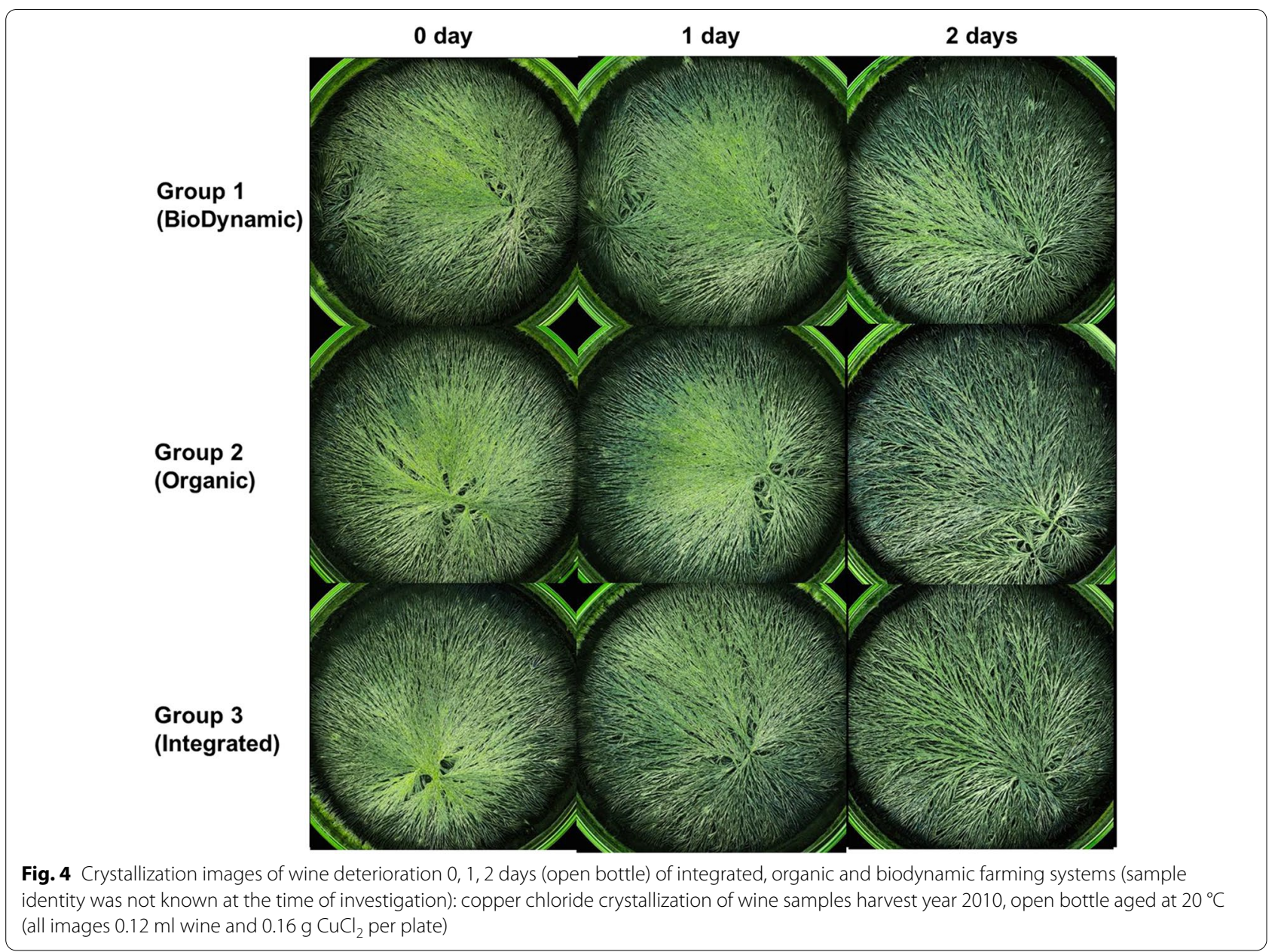

(with compost and legume-rich intercrops) and the integrated treatment (compost, mineral nitrogen and mostly non-leguminous intercrops) resulted in lower contents of soil mineral nitrogen in the period of conversion in the biological treatments, but in the following 3 years it was vice-versa. Consequently, the effect of the production method on the chemical composition of wood, leaves and grapes differed between the period of conversion (lower total acidity in must, high total soluble solids in juice and comparatively high contents of carbon-based wood constituents in biodynamic and organic as compared to integrated treatment) and the following three years (higher nitrogen content in leaves at veraison, higher content of yeast assimilable nitrogen in berries in biodynamic as compared to integrated treatment).

In the current study, the hypotheses were confirmed that (i) the image-forming methods used generate different and complementary information compared to sensory analysis and (ii) with these image-forming methods, wine from the cultivation methods integrated, organic and biodynamic can be differentiated, characterized and classified, as growth processes influenced by site conditions have a significant impact on the product quality of wine. Reduction in vegetative growth, resulting in a slightly higher leaf-area-to-fruitweight-ratio in the organic and biodynamic treatment when assessed in 2012 [4], is a characteristic trait of organic and biodynamic systems both in the INBIODYN trial and worldwide [3] and likely influences juice and wine quality [46]. Therefore, this trait might partly account for differences in wine quality among systems assessed in the current study by image-forming methods and sensory analysis.

With regard to the chemical ingredients, Granato et al. [47] was only able to differentiate between 


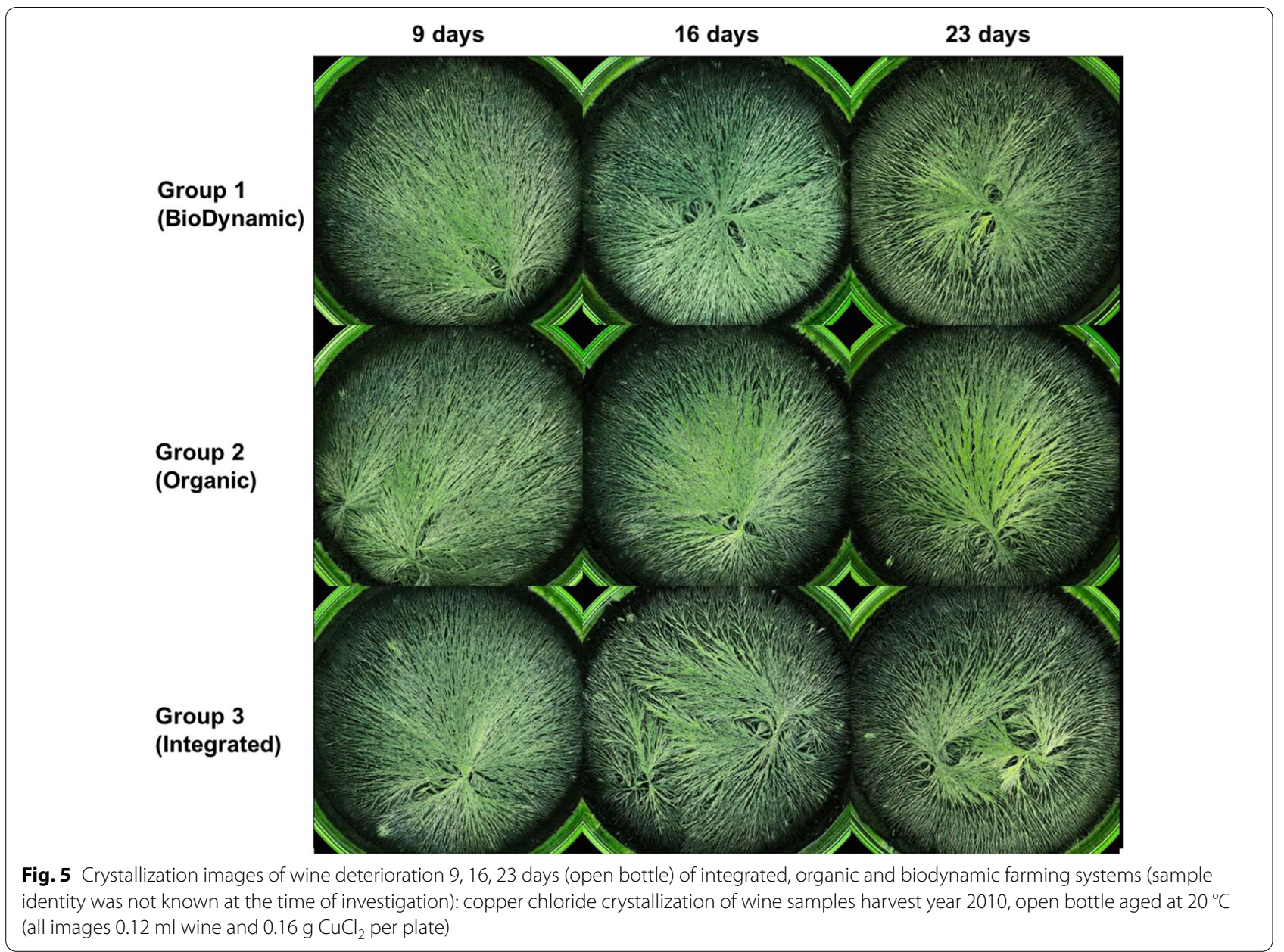

biodynamic and organic wines as a common group compared to conventional wines. Yañez et al. [48] were also able to differentiate between organic and conventional wines with ingredient analyses. In contrast, Tassoni et al. [49] and Plahuta et al. [50] did not differentiate the wines from the three cultivation methods according to ingredients. In Parpinello et al. [36] and Laghi et al. [51], a differentiation between organic and biodynamic wines from one location of two years each was possible by evaluating the chemical ingredients. A sensory differentiation of the organic and biodynamic cultivation methods was possible in Ross et al. [38] and not possible in Parpinello et al. [36], Bigler et al. [52] and Döring et al. [4].

As in sensory analysis, it is difficult to relate differences in structure formation in image-forming methods to the chemical composition of the wine. Wines from the organic and the biodynamic treatment had higher alcohol levels, a higher acidity and more glycerol (Table 2). As part of the main ingredients of the matrix wine, i.e., the physical domain that contains or interacts with the individual chemical components, these parameters are likely to influence sensory evaluation of the wines. The panel ranked the wines in the correct order concerning their acidity, although results were not significant (Table 2, Fig. 7). The content of alcohol and glycerol did not influence the perception of the wines by the sensory panel concerning the descriptor "body".

Even though the food matrix has largely been neglected in food quality research, recent advances in food science show that it can have strong implications on bioaccessibility, bioconversion or bioefficacy in the human body [53]. Likewise, it is known that matrix properties, namely viscosity, influences structure formation in copper chloride crystallization and that viscosity is reduced when juice ages [9]. Therefore, future research should focus on effects of production systems on the food matrix and possible relations to structure formation in image-forming methods. 


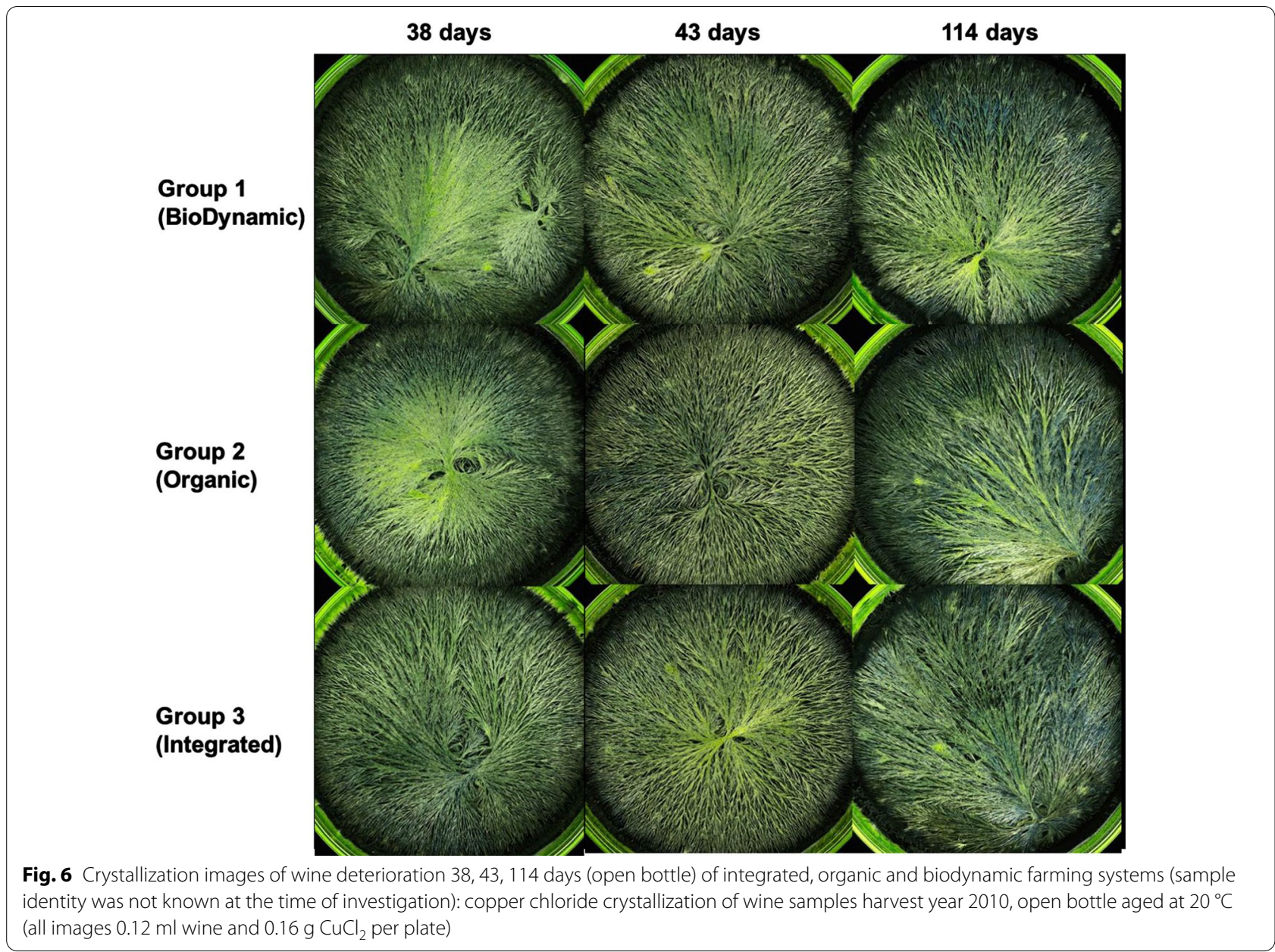

Table 4 Grouped and classified grape samples from different farming systems after decoding

\begin{tabular}{ll}
\hline Year & Grouping and classification \\
\hline 2010 & $\mathrm{D}=\mathrm{D}=\mathrm{D} ; \quad \mathrm{O}=\mathrm{O}=\mathrm{O} ; \quad \mathrm{I}=\mathrm{I}=\mathrm{I}$
\end{tabular}

From left to right (i) samples needed more wine per sample for similar form expression, and (ii) samples showed more pronounced structural features that indicate enhanced aging/deterioration (open wine bottle)

$D$ biodynamic system, $O$ organic system, I integrated system

Further research is also needed with respect to the mode of action of the biodynamic preparations, which may include bacterial regulation [54], resulting in greater rhizospheric activity $[55,56]$ or stimulation of natural defence substances $[57,58]$, possibly via plant hormones $[54,55,59,60]$. When comparing biodynamic with conventional viticulture, Soustre-Gacougnolle et al. [61] found in their studies that biodynamic viticulture was
Table 5 Contingency table of Fisher's exact test (test for grouping of encoded samples)

\begin{tabular}{lccc}
\hline & \multicolumn{2}{c}{ Correct grouping } & \\
\cline { 2 - 4 } & G1 & G2 & G3 \\
\hline Grouping of encoded samples & & \\
G1 & 3 & 0 & 0 \\
G2 & 0 & 3 & 0 \\
G3 & 0 & 0 & 3 \\
Significance & $p=0.004$ & & \\
\hline G1-G3: sample group 1 to 3 & &
\end{tabular}

associated with higher expression of silencing and immunity genes, and higher anti-oxidative and anti-fungal secondary metabolite levels. Soustre-Gacougnolle et al. [61] suggest that the sustainability of biodynamic practices is probably based on fine molecular regulation. 
Table 6 Contingency table of interrater agreement (test for classification of encoded samples)

\begin{tabular}{llll}
\hline & \multicolumn{2}{c}{ Correct classification } & \\
\cline { 2 - 4 } & D & O & I \\
\hline Grouping of encoded samples & & \\
D & 3 & 0 & 0 \\
0 & 0 & 3 & 0 \\
I & 0 & 0 & 3 \\
Significance & $p=0.001$ & & \\
\hline
\end{tabular}

$D$ biodynamic system, $O$ organic system, I integrated system

\section{Conclusions}

The present study shows that the image-forming methods copper chloride crystallization, capillary dynamolysis and circular chromatography can detect quality differences in wine, which are consistent with differences in the physiological development of vines and grapes. The evaluation approach followed in the research presented here adds a new dimension to wine quality research and can make a significant contribution to a better understanding of how different cultivation systems influence plant physiology and thus product quality. With further research, the imageforming methods copper chloride crystallization, capillary dynamolysis and circular chromatography may become a complementary approach to sensory and chemical analysis in wine quality investigations. The image-forming methods can be seen as a resilience test that assesses ageing in terms of degeneration (presumably oxidation). The present experimental results of the image-forming methods lead to the hypothesis that differences in sensory analysis of different cultivation systems are more pronounced when the wine is more oxidized by prolonged air contact. This hypothesis should be tested in further studies.

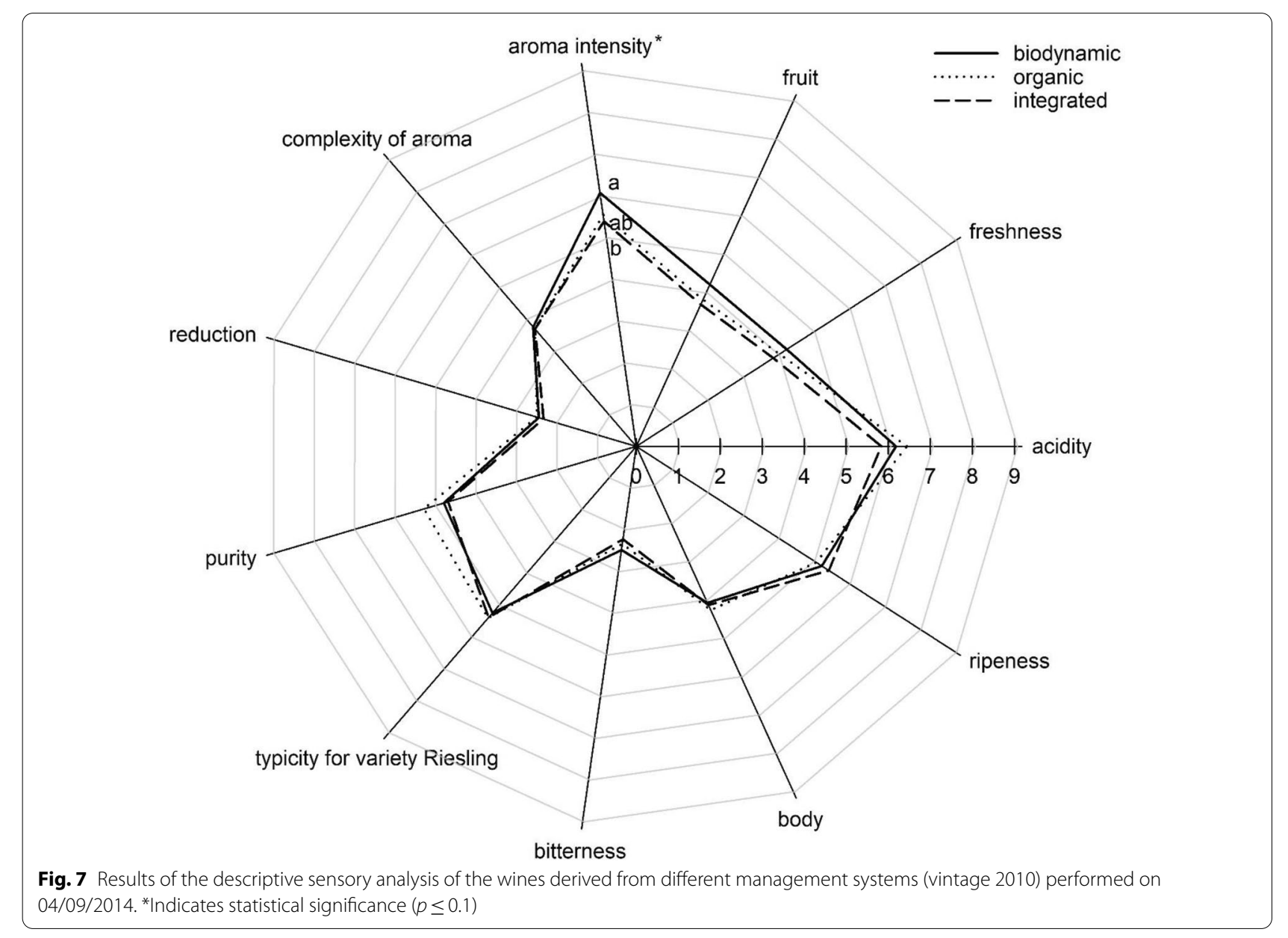




\section{Abbreviations}

D: Biodynamic system; FTIR: Fourier-transform infrared spectroscopy; I: Integrated system; O: Organic system.

\section{Acknowledgements}

The authors gratefully acknowledge funding from Software AG Foundation and Damus Foundation, Germany. Statistical analysis guidance by Prof. Dr. Hans-Peter Piepho, Bioinformatics Department, Institute of Crop Science, Faculty of Agricultural Sciences, University of Hohenheim, and Stefan Mihalache, Institute of Mathematics, University of Cologne, is kindly appreciated. The authors also thank the Department of Grapevine Breeding at Hochschule Geisenheim University for providing the facilities for fermentation of the wines, the Department of Beverage Research at Hochschule Geisenheim University for conducting the FTIR analyses of the wines and Dr. Rainer Jung, Department of Enology at Hochschule Geisenheim University, for his assistance in conducting the sensory analysis.

\section{Authors' contributions}

JF and JD designed the work, interpreted the results and wrote the manuscript. MA interpreted the results and wrote the manuscript. GM, RK and HRS designed the work, interpreted the results and reviewed the manuscript. All authors read and approved the final manuscript.

\section{Funding}

Open Access funding enabled and organized by Projekt DEAL. We would like to thank the Software AG Foundation and Damus Foundation for financially supporting the study. The foundations had no influence on the design of the study and collection, analysis, and interpretation of data and in writing the manuscript.

\section{Availability of data and materials}

All pictures and datasets used and/or analyzed during the current study are available from the corresponding author on reasonable request.

\section{Declarations}

\section{Ethics approval and consent of participate}

Not applicable.

\section{Consent for publication}

Not applicable.

\section{Competing interests}

The authors declare that they have no competing interests.

\section{Author details}

${ }^{1}$ Department of Organic Farming and Cropping Systems, University of Kassel, Nordbahnhofstr. 1a, 37213 Witzenhausen, Germany. ${ }^{2}$ Institute of Crop Science and Resource Conservation, Department of Agroecology and Organic Farming, University of Bonn, Auf dem Hügel 6, 53121 Bonn, Germany. ${ }^{3}$ Department of General and Organic Viticulture, University of Geisenheim, Von-Lade-Str. 1, 65366 Geisenheim, Germany.

Received: 26 July 2021 Accepted: 1 October 2021

Published online: 24 December 2021

\section{References}

1. FIBL IFOAM. The world of organic agriculture — statistics and emerging trends. Frick: Fibl; 2020.

2. Meissner G, Athmann M, Fritz F, Kauer R, Stoll M, Schultz HR. Conversion to organic and biodynamic viticultural practices: impact on soil, grapevine development and grape quality. OENO One. 2019. https://doi.org/ 10.20870/oeno-one.2019.53.4.2403.

3. Döring J, Collins C, Frisch M, Kauer R. Organic and biodynamic viticulture affect biodiversity, vine and wine properties: a systematic quantitative review. Am J Enol Vitic. 2019;70(3):221-42.
4. Döring J, Frisch M, Tittmann S, Stoll M, Kauer R. Growth, yield and fruit quality of grapevines under organic and biodynamic management. PLoS ONE. 2015. https://doi.org/10.1371/journal.pone.0138445.

5. Meissner G. Untersuchungen zu verschiedenen Bewirtschaftungssystemen im Weinbau unter besonderer Berücksichtigung der BiologischDynamischen Wirtschaftsweise und des Einsatzes der Biologisch-Dynamischen Präparate [Investigations on different management systems in viticulture with special consideration of biodynamic farming and the use of biodynamic preparations]. PhD thesis, University Geisenheim; 2015.

6. Cravero MC. Organic and biodynamic wines quality and characteristics: a review. Food Chem. 2019;295:334-40. https://doi.org/10.1016/j.foodc hem.2019.05.149.

7. Busscher N, Kahl J, Doesburg P, Mergardt G, Ploeger A. Evaporation influences on the crystallization of an aqueous dihydrate cupric chloride solution with additives. J Colloid Interf Sci. 2010;334:556-62.

8. Gallinet JP, Gauthier-Manuel B. Wetting of a glass surface by protein adsorption induces the crystallization of an aqueous cupric chloride solution. J Colloid Interf Sci. 1992;148:155-9. https://doi.org/10.1016/ 0021-9797(92)90123-4.

9. Busscher N, Kahl J, Ploeger A. From needles to pattern in food quality determination. J Sci Food Agric. 2014. https://doi.org/10.1002/jsfa.6498.

10. Kokornaczyk MO, Dinelli G, Marotti I, Benedettelli S, Nani D, Betti L. Selforganized crystallization patterns from evaporating droplets of common wheat grain leakages as a potential tool for quality analysis. Sci World J. 2011;11:1712-25. https://doi.org/10.1100/2011/937149.

11. Doesburg P, Huber M, Andersen JO, Athmann M, van der Bie G, Fritz J, Geier U, Hoekman J, Kahl J, Mergardt G, Busscher N. Standardization and performance of a visual gestalt evaluation of biocrystallization patterns reflecting ripening and decomposition processes in food samples. Biol Agric Hortic. 2015. https://doi.org/10.1080/01448765.2014.993705.

12. Fritz J, Athmann M, Kautz T, Köpke U. Grouping and classification of wheat from organic and conventional production systems by combining three image forming methods. Biol Agric Hortic. 2011;27:320-36.

13. Busscher N, Kahl J, Andersen JO, Huber M, Mergardt G, Doesburg P, Paulsen M, Ploeger A. Standardization of the biocrystallization method for carrot samples. Biol Agric Hortic. 2010;27:1-23.

14. Kahl J, Busscher N, Hoffmann W, Mergardt G, Clawin-Raedecker I, Kiesner C, Ploeger A. Development and performance of crystallization with additives applied on different milk samples. Food Anal Methods. 2013. https:// doi.org/10.1007/s12161-013-9759-5.

15. ISO 11035. Sensory analysis: identification and selection of descriptors for establishing a sensory profile by a multidimensional approach. Geneva: International Organization for Standardization; 1994.

16. Huber M, Andersen JO, Kahl J, Busscher N, Doesburg P, Mergardt G, Kretschmer S, Zalecka A, Meelursan A, Ploeger A, Nierop D, van de Vijver $L$, Baars E. Standardization and validation of the visual evaluation of biocrystallizations. Biol Agric Hortic. 2010;27(1):25-40.

17. Andersen JO, Henriksen C, Laursen J, Nielsen AA. Computerised image analysis of biocrystallograms originating from agricultural products. Comput Electron Agric. 1999;22:51-69.

18. Doesburg P, Nierop AFM. Development of a structure analysis algorithm on structures from $\mathrm{CuCl}_{2} .2 \mathrm{H} 2 \mathrm{O}$ crystallization with agricultural products. Comput Electron Agric. 2013;90:63-7.

19. Kahl J, Busscher N, Mergardt G, Mäder P, Torp T, Ploeger A. Differentiation of organic and non-organic winter wheat cultivars from a controlled field trial by crystallization patterns. J Sci Food Agric. 2015;95:53-8.

20. Meelursarn A. Statistical evaluation of texture analysis from the biocrystallization method: effect of image parameters to differentiate samples from different farming systems. PhD thesis, University Kassel; 2007. https:// kobra.bibliothek.uni-kassel.de/handle/urn:nbn:de:hebis34-2007041017 616.

21. Busscher N, Doesburg P, Mergardt G, Sokol A, Kahl J, Ploeger A. Influence of dewetting on the crystallization behavior of $\mathrm{CuCl}_{2}$ in the presence of BSA during evaporation in a Petri dish. Heliyon. 2019;5: e01102. https:// doi.org/10.1016/j.heliyon.2018.e01102.

22. Athmann M. Produktqualität von Salatrauke (Eruca sativa L.) und Weizen (Triticum aestivum L.): Einfluss von Einstrahlungsintensität, Stickstoffangebot, Düngungsart und Hornkieselapplikation auf Wachstum und 
Differenzierung [Product quality of rocket (Eruca sativa L.) and wheat (Triticum aestivum L.): influence of solar radiation, nitrogen supply, fertilizer type and horn silica application on growth and differentiation]. PhD thesis, University Bonn; 2011.

23. Kahl J, Busscher N, Mergardt G, Mäder P, Dubois D, Ploeger A. Authentication of organic wheat samples from a long-term trial using biocrystallization. In: Proceedings of the second scientific conference of the international society of organic agriculture research, Modena, Italy; 2008. p. 742-5.

24. Fritz J, Athmann M, Andersen JO, Doesburg P, Geier U, Mergardt G. Advanced panel training on visual Gestalt evaluation of biocrystallization images: ranking wheat samples from different extract decomposition stages and different production systems. Biol Agric Hortic. 2018;35:21-32.

25. Fritz J, Athmann M, Meissner G, Kauer R, Geier U, Bornhütter R, Schultz HR. Quality assessment of grape juice from integrated, organic and biodynamic viticulture using image forming methods. OENO one. 2020 https://doi.org/10.20870/oeno-one.2020.54.2.2548.

26. Mäder P, Hahn D, Dubois D, Gunst L, Alföldi T, Bergmann H, Oehme M, Amadó R, Schneider H, Graf U, Velimirov A, Fließbach A, Niggli U. Wheat quality in organic and conventional farming: results of a 21 year field experiment. J Sci Food Agric. 2007;87:1826-35.

27. Mäder P, Pfiffner L, Niggli U, Balzer U, Balzer FM, Plochberger A, Velimirov A, Besson JM. Effect of three farming systems (bio-dynamic, bio-organic conventional) on yield and quality of beetroot (Beta Vulgaris L. Var. SCulenta L.) in a seven year crop rotation. Acta Hortic. 1993;339:10-31.

28. Weibel F, Bickel R, Leuthold S, Alföldi T, Balzer-Graf U. Are organically grown apples tastier and healthier? A comparative study using conventional and alternative methods to measure fruit quality. Acta Hortic. 2000;517:417-27.

29. Danner R. Vergleichende Untersuchungen zum konventionellen, organisch-biologischen und biologisch-dynamischen Weinbau. [Comparative studies on conventional, organic-biological and biodynamic viticulture]. Wien: PhD thesis, Universität für Bodenkultur Wien, Wien; 1985.

30. Kauer R. Vergleichende Untersuchungen zum integrierten und ökologischen Weinbau in den ersten drei Jahren der Umstellung: Ergebnisse von 12 Standorten im Anbaugebiet Rheinhessen bei den Rebsorten MüllerThurgau und Riesling. [Comparative studies on integrated and organic viticulture in the first three years of conversion: results from 12 sites in the Rheinhessen production area for the grape varieties Müller-Thurgau and Riesling]. PhD thesis, Justus-Liebig-Universität Gießen; 1994.

31. Dupin I, Fischer U, Schlich P. Differentiation of wines produced by organic or conventional viticulture according to their sensory profiles and aroma composition. Am J Enol Vitic. 2000;51:299.

32. Martin KR, Rasmussen KK. Comparison of sensory qualities of geographically paired organic and conventional red wines from the southwestern US with differing total polyphenol concentrations: a randomized pilot study. Food Nutr Sci. 2011;02:1150-9.

33. Collins C, Penfold CM, Johnson LF, Bastian S, Marschner P. The relative sustainability of organic, biodynamic and conventional viticulture. Montpellier: GiESCO, Peche Rouge; 2015. p. 53-5.

34. Beni C, Rossi G. Conventional and organic farming: estimation of some effects on soil, copper accumulation and wine in a Central Italy vineyard. Agrochimica. 2009:53:145-59.

35. Henick-Kling T. Summary of effects of organic and conventional grape production practices on juice and wine composition. In: Pool RM, editor. 3rd organic grape and wine production symposium; 1995. p. 89-102.

36. Parpinello GP, Rombolà AD, Simoni M, Versari A. Chemical and sensory characterisation of sangiovese red wines: comparison between biodynamic and organic management. Food Chem. 2016;167:145-52.

37. Patrignani F, Montanari C, Serrazanetti DI, Braschi G, Vernocchi P, Tabanelli G, Parpinello GP, Versari A, Gardini F, Lanciotti R. Characterization of yeast microbiota, chemical and sensory properties of organic and biodynamic Sangiovese red wines. Ann Microbiol. 2017;67:99-109.

38. Ross CF, Weller KM, Blue RB, Reganold JP. Difference testing of merlot produced from biodynamically and organically grown wine grapes. J Wine Res. 2009:20:85-94.

39. Parpinello GP, Ricci A, Rombolà AD, Nigro G, Versari A. Comparison of Sangiovese wines obtained from stabilized organic and biodynamic vineyard management systems. Food Chem. 2019;283:499-507. https://doi.org/10. 1016/j.foodchem.2019.01.073.
40. Picchi M, Canuti C, Bertuccioli M, Zanoni B. The influence of conventional and biodynamic winemaking processes on the quality of sangiovese wine. Int J Wine Res. 2020;12:1-16.

41. Fritz J, Athmann M, Meissner G, Kauer R, Köpke U. Quality characterization via image forming methods differentiates grape juice produced from integrated, organic or biodynamic vineyards in the first year after conversion. Biol Agric Hortic. 2017. https://doi.org/10.1080/01448765.2017. 1322003.

42. Zalecka A, Kahl J, Doesburg P, Pyskow B, Huber M, Skjerbaek K, Ploeger A. Standardization of the steigbild method. Biol Agric Hort. 2010;27:41-57.

43. Agresti A. Categorical data analysis. 2nd ed. Hoboken: John Wiley \& Sons Inc; 2002.

44. Nikolaus F. Sensorische und analytische Untersuchungen zu Weinen aus verschiedenen Bewirtschaftungssystemen. [Sensory and analytical studies on wines from different cultivation systems]. Geisenheim: Bachelor Thesis at Hochschule Geisenheim University; 2014.

45. Ihaka R, Gentleman R. R: a language for data analysis and graphics. J Comput Graph Stat. 1996;5(3):299-314.

46. Kliewer WM, Dokoozlian NK. Leaf area/crop weight ratios of grapevines: influence on fruit composition and wine quality. Am J Enol Vitic. 2005;56(2):170-81.

47. Granato D, Margraf T, Brotzakis I, Capuano E, van Ruth SM. Characterization of conventional, biodynamic, and organic purple grape juices by chemical markers, antioxidant capacity, and instrumental taste profile. J Food Sci. 2015;80:55-65.

48. Yañez L, Saavedra J, Martínez C, Córdova A, Ganga MA. Chemometric analysis for the detection of biogenic amines in Chilean Cabernet Sauvignon wines: a comparative study between organic and nonorganic production. J Food Sci. 2012;77:143-50.

49. Tassoni A, Tango N, Ferri M. Comparison of biogenic amine and polyphenol profiles of grape berries and wines obtained following conventional, organic and biodynamic agricultural and oenological practices. Food Chem. 2013;139:405-13.

50. Plahuta P, Raspor P. Comparison of hazards: current vs GMO wine.' Food Control. 2007:18:492-502.

51. Laghi L, Versari A, Marcolini E, Parpinello GP. Metabonomic investigation by $1 \mathrm{H}$-NMR to discriminate between red wines from organic and biodynamic grapes. Food Nutr Sci. 2014;5:52-9.

52. Bigler C, Levite D, van der Meer M, Kaufmann A, Weibel FP. Rotwein unter Hochspannung: Mehrjährige Qualitäts-Untersuchung mit Gas-DischargeVisualisation (GDV) [Red wine under high voltage: Several-year quality study with gas discharge visualisation (GDV)]. In: Mayer J, editor. Beiträge zur 10. Wissenschaftstagung Ökologischer Landbau, ETH Zürich, 11-13. Februar 2009. Berlin, Germany: press Dr. Köster, Band 2; 2009. p. 440-3.

53. Aguilera JM. The food matrix: implications in processing, nutrition and health. Crit Rev Food Sci Nutr. 2019;59(22):3612-29.

54. Spaccini R, Mazzei P, Squartini A, Giannattasio M, Piccolo A. Molecular properties of a fermented manure preparation used as field spray in biodynamic agriculture. Environ Sci Pollut Res Int. 2012;19(9):4214-25. https://doi.org/10.1007/s11356-012-1022-x.

55. Giannatasio M, Vendramin E, Fornasier F, Alberghini S, Zanardo M, Stellin F, Concheri G, Stevenato P, Ertani A, Nardi S, Rizzi V, Piffanelli P, Spaccini R, Mazzei P, Piccolo A, Sqartini A. Microbiological features and bioactivity of a fermented manure product (preparation 500) used in biodynamic agriculture. J Microbiol Biotechnol. 2013;23(5):644-51. https://doi.org/10. 4014/jmb.1212.12004.

56. Reeve JR, Capenter-Boggs L, Reganold JP, York AL, Brinton WF. Influence of biodynamic preparations on compost development and resultant compost extracts on wheat seedling growth. Bioresour Technol. 2010;101(14):5658-66. https://doi.org/10.1016/j.biortech.2010.01.144.

57. Botelho RV, Roberti R, Tessarin P, García-Mina JM, Rombolà AD. Physiological responses of grapevines to biodynamic management. Renew Agric Food Syst. 2016;31(5):402-13. https://doi.org/10.1017/S17421705150003 20.

58. Schneider S, Ullrich WR. Differential induction of resistance and enhanced enzyme activities in cucumber and tobacco caused by treatment with various abiotic and biotic inducers. Physiol Mol Plant Pathol. 1994;45(4):291-304. https://doi.org/10.1016/S0885-5765(05)80060-8. 
59. Fritz J. Reaktionen von Pflücksalat (Lactuca sativa L. var. crispa) und Buschbohnen (Phaseolus vulgaris L. var. nanus) auf das Spritzpräparat Hornkiesel. [Reactions of plucking lettuce (Lactuca sativa L. var. crispa) and bush beans (Phaseolus vulgaris L. var. nanus) to the spray preparation horn silica]. PhD thesis, University Bonn; 2000.

60. Radha TK, Rao DLN. Plant growth promoting bacteria from cow dung based biodynamic preparations. Indian J Microbiol. 2014;54(4):413-8. https://doi.org/10.1007/s12088-014-0468-6.

61. Soustre-Gacougnolle I, Lollier M, Schmitt C, Perrin M, Buvens E, Lallemand JF, Mermet M, Henaux M, Thibault-Carpentier C, Dembelé D, Steyer D,
Clayeux C, Moneyron A, Masson JE. Responses to climatic and pathogen threats differ in biodynamic and conventional vines. Sci Rep. 2018. https://doi.org/10.1038/s41598-018-35305-7.

\section{Publisher's Note}

Springer Nature remains neutral with regard to jurisdictional claims in published maps and institutional affiliations.

\section{Submit your manuscript to a SpringerOpen ${ }^{\circ}$ journal and benefit from:}

- Convenient online submission

- Rigorous peer review

- Open access: articles freely available online

- High visibility within the field

- Retaining the copyright to your article

Submit your next manuscript at $\boldsymbol{\nabla}$ springeropen.com 